\title{
Airborne geophysics as a tool for geoscientific research in Antarctica: Some recent examples
}

\author{
F. Ferraccioli, ${ }^{1}$ P. C. Jones, ${ }^{1,2}$ P. Leat, ${ }^{1}$ and T. A. Jordan ${ }^{1}$ \\ ${ }^{1}$ British Antarctic Survey, High Cross, Madingley Road, Cambridge, CB3 0ET, UK (ffe@bas.ac.uk) \\ ${ }^{2}$ now at: ARKeX Ltd. Newton House, Cambridge Business Park, Cowley Road, Cambridge, CB4 OWZ UK
}

\begin{abstract}
The polar regions play an important role in Earth's geodynamic and climatic systems. Modern airborne geophysical surveys combine radio-echo sounding, aeromagnetic and aerogravity methods to explore the geology of these regions. This paper reviews some recent aerogeophysical investigations undertaken by the British Antarctic Survey to: 1) Image subglacial rifts of Jurassic age in western Dronning Maud Land, which were associated with early Gondwana break-up; 2) Investigate crustal growth over the Antarctic Peninsula by Cretaceous arc magmatism and terrane accretion along the paleo-Pacific margin of Gondwana; 3) Analyse geological boundary conditions for presentday ice dynamics over Coats Land.

Citation: Ferraccioli1, F., P. C. Jones, P. Leat, and T. A. Jordan (2007), Airborne geophysics as a tool for geoscientific research in Antarctica: Some recent examples: in Antarctica: A Keystone in a Changing World-Online Proceedings of the 10th ISAES, edited by A.K. Cooper and C.R. Raymond et al., USGS Open-File Report 2007-1047, Short Research Paper 056, 4 p.; doi:10.3133/of2007-1047.srp056
\end{abstract}

\section{Introduction}

Antarctic geology plays an important role in ice sheet dynamics and stability, which affects past, present and future global sea-level change. The progressive break-up of Gondwana led to the final isolation of Antarctica, which in turn was key to the establishment of Antarctic ice sheets (Fitzgerald, 2002). Antarctic geology is therefore an important element in order to improve our understanding of the Earth System. However, geological and geophysical studies over Antarctica are often hampered by the extensive ice cover of the East and West Antarctic Ice Sheets. It is therefore not surprising that while we enter the first year of the IPY (2007-2009) several Antarctic regions still represent the last frontiers of our planet. Airborne geophysics provides an important tool to explore these ice covered crustal domains. Extensive airborne geophysical exploration has been undertaken by several international groups over the last

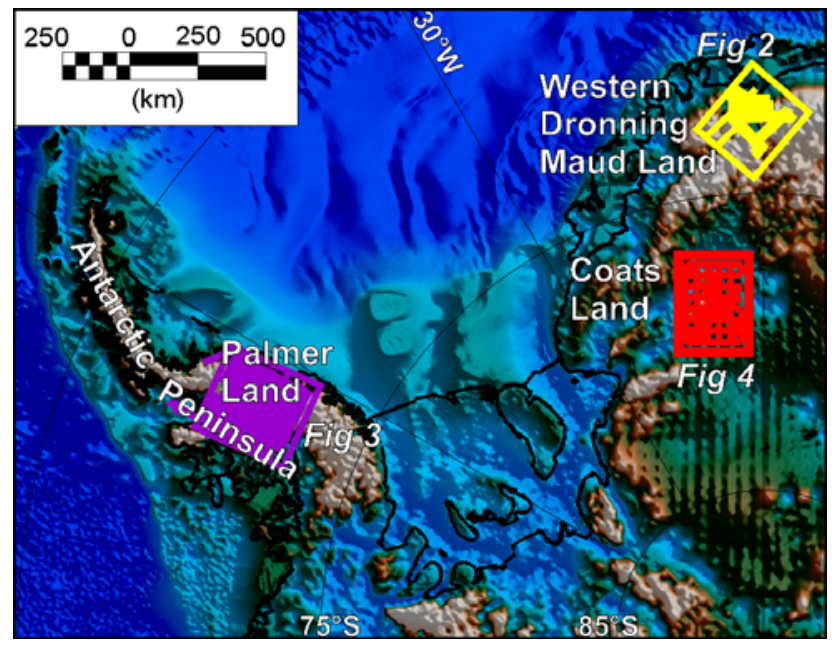

Figure 1. Location of recent BAS aerogeophysical surveys superimposed on BEDMAP topography. Yellow box: MAMOG; purple: SPARC; red: AFI. decades and compilations of airborne radar and aeromagnetic data have further enhanced their utility and availability for polar geosciences (Lythe et al., 2001; Golynsky et al., 2006).

In 70's the Russian Antarctic Programme pioneered the use of a multi-instrumented IL-14 aircraft equipped with radar, aeromagnetic and airborne gravity sensors (e.g. Aleshkova et al., 2000). In the 90's the US Antarctic Programme utilised a Twin Otter aircraft equipped with similar sensors for integrated studies of Antarctic geology and glaciology (e.g. Blankenship et al., 1993; 2001; Behrendt et al., 1996; 2004; Bell et al., 1998; 2002; Studinger et al., 2001, 2003 and 2004). In our paper we review some aerogeophysical surveys flown since 200102 by the British Antarctic Survey (BAS) as part of several geological and glaciological research projects in East and West Antarctica (Fig. 1). These surveys provide recent examples of the significant potential of aerogeophysics as a tool for geosciences in Antarctica.

\section{High-resolution aerogeophysics over Dronning Maud Land: a new case study for glaciated continental rift imaging}

A high-resolution aerogeophysical survey was flown using a BAS Twin Otter over western Dronning Maud Land (Fig. 2), as part of the MAMOG project (Magmatism as a Monitor of Gondwana break-up), which included structural geology, petrology, geochemistry, geochronology and AMS studies. The aim was to improve our understanding of crustal and mantle processes, which led to early Gondwana break-up between East Antarctica and South Africa (Jokat et al., 2003). Although geological studies suggested that the Jutulstraumen and Pencksökket ice streams could conceal continental rifts related to Jurassic extension (Grantham, 1996) land-gravity observations and previous aeromagnetics did not yield unambiguous evidence for rifting (Corner, 1994). Our high-resolution aerogeophysical survey was flown with 


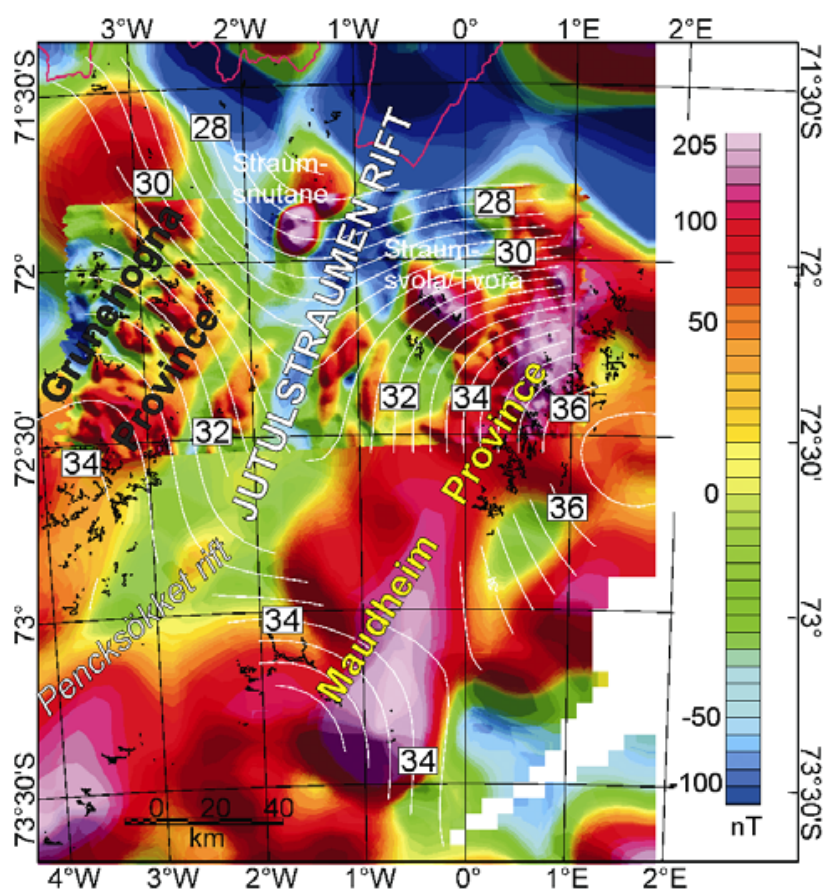

Figure 2. New aeromagnetic map for the Jutulstraumen Rift region with estimates of crustal thickness superimposed.

line spacing of $1 \mathrm{~km}$ and tie lines $8 \mathrm{~km}$ apart to image possible rifts and associated magmatic patterns in greater detail than possible with previous reconnaissance data. Radio-echo sounding data revealed the deep subglacial trench where the Jutulstraumen Ice Stream flows.

Figure 2 shows a new aeromagnetic map obtained by combining the recent high-resolution survey data (Ferraccioli et al., 2005a) with the previous regional ADMAP grid (Golynsky et al., 2002). Crustal thickness estimates obtained by 3D inversion of airborne gravity data are also superimposed (Ferraccioli et al., 2005b). The newly compiled aeromagnetic data trace at more regionalscale the buried tectonic boundary between an Archean craton, known as the Grunehogna Province and the Late Proterozoic to Cambrian mobile belt, dubbed the Maudheim Province (Perritt and Watkeys, 2003). This inherited structure controlled the location of the later Jurassic rift. Although significant crustal thinning occurred beneath the Jutustraumen (see Fig. 2 and Ferraccioli et al., 2005b) the rift was largely amagmatic, when compared to the conjugate(?) Jurassic rifts in South Africa (Jourdan et al., 2004). This finding is intriguing since geochemical evidence suggests that western Dronning Maud Land was the locus of an incubated mantle plume in the Jurassic (Riley et al., 2005), which would be expected to generate substantial volumes of magmatism.

The results of this high-resolution survey confirm the utility of aerogeophysics when studying glaciated continental rifts, thereby expanding on previous case studies over the West Antarctic Rift System (Behrendt,
1999), the Transantarctic Mountains and Marie Byrd Land rift flanks (Ferraccioli and Bozzo, 1999; Ferraccioli et al., 2001; Ferraccioli et al., 2002a), and the Lambert Rift (Golynsky et al., 2002).

\section{Aerogeophysical survey over Palmer Land: a new case study for glaciated terrane analysis}

Aeromagnetic and airborne gravity data were collected over Palmer Land using a BAS Dash-7 aircraft as part of a multi-disciplinary geological project (SPARC: Superterranes of the Pacific Margin Arc), aimed at testing a terrane hypothesis for the Antarctic Peninsula (Vaughan et al., 2000). The Antarctic Peninsula has traditionally been regarded as a complete arc-trench system, built in situ on pre-existing Gondwana basement (Storey and Garrett, 1985). However, structural evidence for a major fault zone fringing the Antarctic Peninsula magmatic arc and dubbed the Eastern Palmer Land Shear Zone, has led to an alternative terrane accretion model for the Antarctic Peninsula (Vaughan et al., 2002). The original terrane hypothesis involved Mesozoic docking of a coherent exotic(?) arc terrane, the Central Domain, against the rifted Gondwana margin (the Eastern Domain).

Figure 3 shows a new aeromagnetic anomaly map derived from the SPARC dataset (Ferraccioli et al., 2006). The new map is derived from upward-continuation, a transformation that has the effect of emphasizing deeper crustal sources. It highlights the remarkable contrast in aeromagnetic signatures over the western and eastern part of the arc within the Central Domain, suggesting the

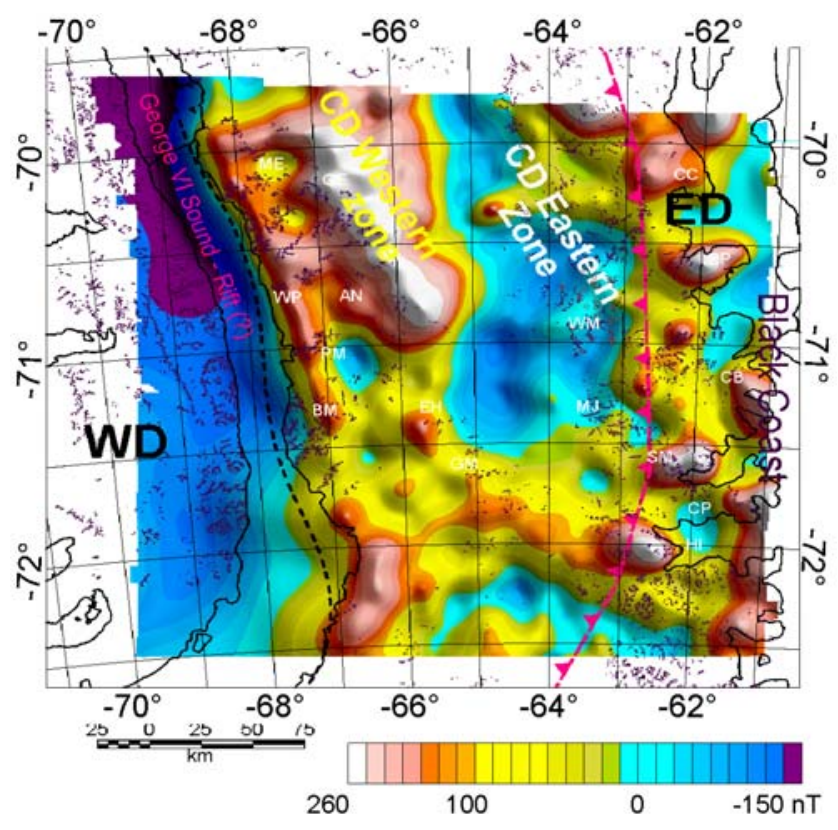

Figure 3. Upward continued aeromagnetic anomaly map $(10 \mathrm{~km})$ showing the contrast between the highly magnetic western magmatic arc within the Central Domain (CD) and the weakly magnetic eastern arc. WD and ED: Western and Eastern domains. 
existence of two different segments within the magmatic arc. Segmentation of the arc into two segments is also observed from a low-pass filtered isostatic anomaly map, which suggests that the western arc has a higher bulk crustal density, compared to the eastern arc (Ferraccioli et al., 2006). A similar density distribution, coupled with contrasting magnetic signatures is also observed over the Peninsular Ranges Batholith in California (Johnson et al., 1999). In analogy with tectonic models for California the western exotic(?) arc of the Antarctic Peninsula may have docked against the authochtonous(?) eastern arc, therefore causing the 107-103 Ma deformation observed over Palmer Land (Ferraccioli et al., 2006). The results of this survey show the utility of aerogeophysics for Mesozoic terrane studies in Antarctica, in addition to previously investigated Paleozoic (Finn et al., 1999; Ferraccioli et al., 2002b) and Precambrian terranes (Golynsky et al., 2002).

\section{Aerogeophysical survey over Coats Land: A new case study for geological controls on ice flow}

A complex pattern of enhanced ice flow involving ice stream tributaries, which extend into the interior of East Antarctica, has been imaged from synthetic aperture radar interferometry and balanced velocities (Bamber et al., 2000). Previous aerogeophysics suggest that tectonic features such as rift basins with sedimentary infill and subglacial volcanoes within the West Antarctic Rift System exert a profound influence on the dynamic behaviour of the overlying West Antarctic Ice Sheet (Blankenship et al., 1993; 2001; Bell et al., 1998; Studinger et al., 2001). However, what geology underlies enhanced flow systems in East Antarctica remains elusive due to the lack of comparable geophysical exploration.

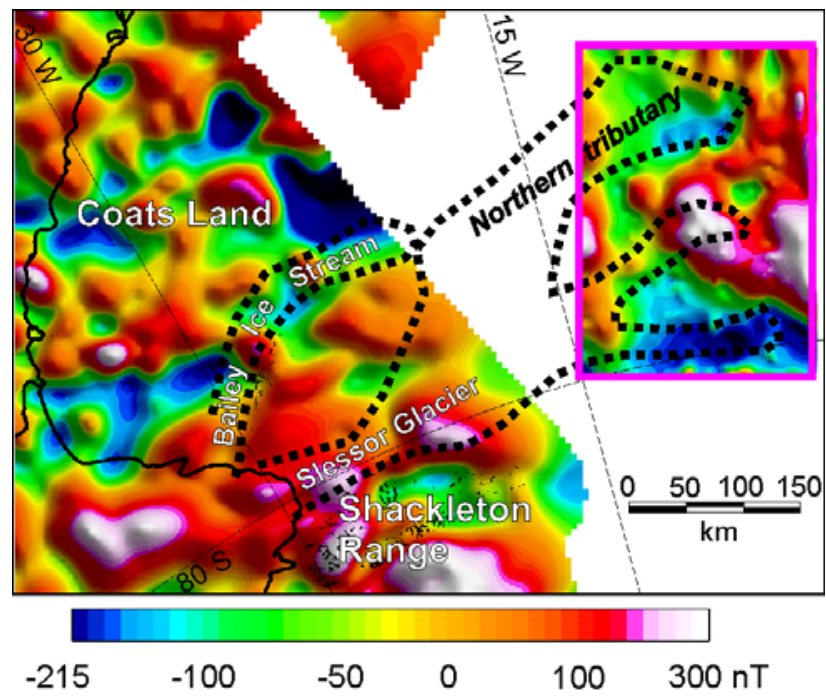

Figure 4. New aeromagnetic anomaly map for Coats Land.

BAS flew an airborne geophysical survey (AFI) over two enhanced flow features in the Bailey/Slessor region of East Antarctica to provide a new window on the underlying geology. Figure 4 shows a new aeromagnetic map derived by combining the recent AFI dataset (Bamber et al., 2006) with ADMAP. While airborne radar data yields basal topography and terrain roughness, aeromagnetic imaging reveals subglacial geology (Shepherd et al., 2006). A grid of the residual aeromagnetic anomalies imaged a region of low-magnetic susceptibility beneath the northern tributary of Slessor Glacier. An inversion technique (Werner Deconvolution), coupled with forward modeling revealed a $3 \mathrm{~km}$-thick sedimentary basin under the northern tributary of Slessor Glacier. The aeromagnetic evidence for a major sedimentary basin beneath the northern tributary of the Slessor Glacier shows that subglacial sediments are potentially an important geological boundary condition for enhanced ice flow, not only in West Antarctica (Blankenship et al., 2001; Studinger et al., 2001), but also in East Antarctica (Shepherd et al., 2006). The new aeromagnetic map presented here (Fig. 4) shows that the sedimentary basin underlying the Slessor Glacier lies parallel to E-W trending Pan-African age thrust faults of the Shackleton Range (Fig. 2 in Kleinschmidt et al., 2002), suggesting that this ancient tectonic grain exerts a regionally significant control on the location of presentday ice flow systems.

Acknowledgments. This paper is a contribution to the Long-Term Survey and Monitoring Programme of BAS. We acknowledge the careful reviews by Ralph von Frese, Sasha Golynsky, Jack Holt, and the constructive suggestions of co-editor Michael Studinger who handled this paper. We also gratefully acknowledge the BAS Air-Unit pilots without which none of these successful surveys would have been possible.

\section{References}

Aleshkova, N.D., A.V. Golynsky, R.G. Kurinin, and V.S. Mandrikov (2000), Gravity mapping in the southern Weddell Sea region (explanatory note for free-air and Bouguer anomaly maps), Polarforschung 67(3), 163-177.

Bamber, J.L., D.G. Vaughan and I. Joughin (2000), Widespread complex flow in the interior of the Antarctic ice sheet, Science 287 (5456), 1248-1250.

Bamber, J.L., F. Ferraccioli, I. Joughin, T. Shepherd, D.M. Rippin, M. J. Siegert, and D.G. Vaughan (2006), East Antarctic ice stream tributary underlain by major sedimentary basin, Geology 34(1), 33-36; doi: 10.1130/G22160.1.

Behrendt, J.C., R. Saltus, D. Damaske, A. McCafferty, C.A. Finn, D.D., Blankenship, and R.E. Bell (1996), Patterns of late Cenozoic volcanic and tectonic activity in the West Antarctic rift system revealed by aeromagnetic surveys, Tectonics 15, 660-676

Behrendt J.C. (1999), Crustal and lithospheric structure of the West Antarctic Rift System from geophysical investigations - a review, Glob. Planet. Change 23, 25-44.

Behrendt, J.C., D.D. Blankenship, D.L. Morse, and R.E. Bell (2004), Shallow-source aeromagnetic anomalies over the West Antarctic Ice Sheet compared with coincident bed topography from radar ice sounding - new evidence for glacial "removal" of subglacially erupted late Cenozoic rift-related volcanic edifices, Global and Planetary Change, 42, 177-193.

Bell, R.E., D.D. Blankenship, C.A. Finn, D.L. Morse, T.A. Scambos, J.M. Brozena, S.M. Hodge, (1998), Influence of subglacial geology on the onset of a West Antarctic ice stream from aerogeophysical observations, Nature 394 (6688), 58-62.

Bell, R.E., M. Studinger, A.A. Tikku, G.K.C. Clarke, M.M. Gutner and C. Meertens (2002), Origin and fate of Lake Vostok water frozen to the base of the East Antarctic ice sheet, Nature, 416, 307-310. 
Blankenship, D. D., R.E. Bell, S.M. Hodge, J.M. Brozena, J.C. Behrendt, and C.A. Finn (1993), Active volcanism beneath the West Antarctic ice sheet and implications for ice-sheet stability, Nature 361, 526-529.

Blankenship, D.D., D.L. Morse, C.A. Finn, R.E. Bell, M.E. Peters, S.D. Kempf, S.M. Hodge, M. Studinger, J.C. Behrendt, and J.M. Brozena (2001), Geologic controls on the initiation of rapid basal motion for West Antarctic ice streams: A geophysical perspective including new airborne radar sounding and laser altimetry results, in The West Antarctic Ice Sheet: Behavior and Environment, edited by R.A. Binschadler, pp. 105-121, American Geophysical Union, Washington, D.C.

Corner, B., (1994), Geological evolution of western Dronning Maud Land within a Gondwana framework: geophysics subprogramme, Final Project Report to SACAR.

Ferraccioli, F. and Bozzo E. (1999), Inherited crustal features and tectonic blocks of the Transantarctic Mountains: an aeromagnetic perspective (Victoria Land - Antarctica), J. Geophys. Res., 104, 11, 25297-25319.

Ferraccioli, F., Coren F., Bozzo E., Zanolla C., Gandolfi S., Tabacco I. and Frezzotti M. (2001), Rifted(?) crust at the East Antarctic Craton margin: gravity and magnetic interpretation along a traverse across the Wilkes Subglacial Basin region, Earth and Planet. Sci. Lett., 197, 407421.

Ferraccioli, F., E. Bozzo, D. Damaske (2002a), Aeromagnetic signatures over western Marie Byrd Land provide insight into magmatic arc basement, mafic magmatism and structure of the eastern Ross Sea Rift flank, Tectonophys., 347, 139-165.

Ferraccioli F., E. Bozzo, and G. Capponi (2002b), Aeromagnetic and gravity anomaly constraints for an early Paleozoic subduction system of Victoria Land, Antarctica, Geophys. Res. Lett., 29 (10), doi:10.1029/2001GL014138.

Ferraccioli, F., P.C. Jones, M.L. Curtis, P.T. Leat, and T.R. Riley (2005a), Tectonic and magmatic patterns in the Jutulstraumen rift(?) region, East Antarctica, as imaged by high-resolution aeromagnetic data, Earth Planets Space, 57, 767-780.

Ferraccioli, F., P.C. Jones, M.L. Curtis and P.T. Leat (2005b), Subglacial imprints of early Gondwana break-up as identified from high resolution aerogeophysical data over western Dronning Maud Land, East Antarctica, Terra Nova 17, 573-579.

Ferraccioli, F. , P.C. Jones, A. P. M. Vaughan, and P. T. Leat (2006), New aerogeophysical view of the Antarctic Peninsula: More pieces, less puzzle, Geophys. Res. Lett., 33, L05310, doi:10.1029/2005GL024636.

Finn, C., Moore, D., Damaske, D., Mackey, T. (1999), Aeromagnetic legacy of early Paleozoic subduction along the Pacific margin of Gondwana. Geology 27 (12), 1087-1090.

Fitzgerald, P. (2002), Tectonics and landscape evolution of the Antarctic plate since the breakup of Gondwana, with an emphasis on the West Antarctic Rift System and the Transantarctic Mountains. In: Gamble J.A., D.N.B. Skinner, S. Henrys (eds.) Antarctica at the close of a millennium. Proceedings of the 8th International Symposium on Antarctic Earth Sciences, Royal Society of New Zealand Bulletin, 35, SIR publishing, 453-469.

Golynsky, A.V., Alyavdin, S.V., Masolov, V.N., Tscherinov, A.S., and Volnukhin, V.S (2002), The composite magnetic anomaly map of East Antarctica. Tectonophys. 347, 109-120.

Golynsky, A., and 10 others (2006), ADMAP- A Digital Magnetic Anomaly Map of the Antarctic. Contributions to global Earth Sciences, edited by Fütterer D.K., Damaske D., Kleinschmidt G., Miller H., Tessensohn F., eds.) Springer-Verlag, Berlin Heidelberg New York, 109-116.

Grantham, G. H. (1996), Aspects of Jurassic magmatism and faulting in western Dronning Maud Land, Antarctica: implications for Gondwana breakup, in Weddell Sea Tectonics and Gondwana Break-up, edited by B. C. Storey, E. C. King and R. A. Livermore, Geol. Soc. Spec. Publ., 108, 63-73.

Johnson, S. E., M. C. Tate, and M. C. Fanning (1999), New geologic mapping and SHRIMP U-Pb zircon data in the Peninsular Ranges batholith, Baja California, Mexico: Evidence for a suture?, Geology, 27, 743-746.
Jokat, W., T. Boebel, M. König, and U. Meyer (2003), Timing and geometry of early Gondwana breakup, J. Geophys. Res., 108(B9), 2428, doi:10.1029/2002JB001802.

Jourdan, F., and 7 others (2004), The Karoo triple junction questioned: evidence from Jurassic and Proterozoic 40Ar/39Ar ages and geochemistry of the giant Okavango dyke swarm (Botswana), Earth Planet. Sci. Lett., 222, 989-1006.

Kleinschmidt G., Buggish W., Läufer A., Helferich S., and F. Tessensohn (2002), The "Ross orogenic" structures in the Shackelton Range and their meaning for Antarctica, In: Gamble J.A., D.N.B. Skinner, S. Henrys (eds.) Antarctica at the close of a millennium. Proceedings of the 8th International Symposium on Antarctic Earth Sciences, Royal Society of New Zealand Bulletin, 35, SIR publishing, 75-83.

Lythe M.B., Vaughan D.G., \& BEDMAP Consortium (2001), BEDMAP, a new ice thickness and subglacial topographic model of Antarctica, J. Geophys. Res., 106, 11335-11351.

Perritt, S. H. and M. K. Watkeys (2003), Implications of late PanAfrican shearing in western Dronning Maud Land, Antarctica, in Intraplate strike-slip Deformation Belts, edited by F. Storti, R. E. Holdsworth, and F. Salvini, Geol. Soc., London, Spec. Pub., 210, 135-143.

Riley, T.R., Leat, P.T, Curtis, M.L., Millar, I.L. and Fazel, A. (2005), Early-Middle Jurassic Dolerite Dykes from Western Dronning Maud Land (Antarctica): Identifying Mantle Sources in the Karoo Large Igneous Province. J. Petrol., 46, 1489-1524.

Shepherd, T., Bamber, J.L., and F. Ferraccioli (2006), Subglacial geology in Coats Land, East Antarctica, revealed by airborne magnetics and radar sounding, Earth and Planetary Science Letters, 244, 323-335.

Storey, B. C., and S. W. Garrett (1985), Crustal growth of the Antarctic Peninsula by accretion, magmatism and extension, Geol. Mag., 122, 5- 14 .

Studinger, M., R.E. Bell, D.D. Blankenship, C.A. Finn, R.A. Arko, D.L. Morse, I. Joughin (2001), Subglacial sediments: a regional geological template for ice flow in West Antarctica, Geophys. Res. Lett. 28, 3943-3946, doi: 10.1029/2000GL011788.

Studinger, M. and 11 others. (2003), Ice cover, landscape setting, and geological framework of Lake Vostok, East Antarctica, Earth Planet. Sci. Lett., 205(3-4), 195-210.

Studinger, M., R.E Bell, W.R. Buck, G.D. Karner, and Blankenship, D.D. (2004), Sub-ice geology inland of the Transantarctic Mountains in light of new aerogeophysical data, Earth Planet. Sci. Lett., 220, 391-408.

Vaughan, A. P. M., and B. C. Storey (2000), The eastern Palmer Land shear zone: A new terrane accretion model for the Mesozoic development of the Antarctic Peninsula, J. Geol. Soc. London, 157, 1243- 1256

Vaughan, A. P. M., S. P. Kelley, and B. C. Storey (2002), MidCretaceous ductile deformation on the eastern Palmer Land shear zone, Antarctica, and implications for timing of Mesozoic terrane collision, Geol. Mag.,139, 465-471 